\title{
The non-equilibrium landscape of the southern Sierra Nevada, California
}

\author{
Marin K. Clark, Gweltaz Maheo, Jason Saleeby, and Kenneth A. Farley, California \\ Institute of Technology, MS 100-23, Pasadena, California 91125, USA, mclark@gps. \\ caltech.edu
}

\section{ABSTRACT}

The paleoelevation of the Sierra Nevada, California, is important to our understanding of the Cenozoic geodynamic evolution of the North America-Pacific plate boundary, and the current debate is fueled by data that argue for conflicting elevation histories. The non-equilibrium or transient landscape of the Sierra Nevada contains information about both past and present controls on the topography of the range. Using geomorphology and thermochronometry, two parts of the landscape of different geodynamic significance and age can be identified: (1) a long-lived, slowly eroding low-relief highland or relict landscape, which we relate to a period of lower relief and elevation from 80-32 Ma; and (2) younger, rapidly-incising river gorges created by at least two stages of elevation and relief increase since $32 \mathrm{Ma}$. Our data argue for moderate range elevation of $\sim 1500$ $\mathrm{m}$ at the cessation of arc magmatism in Late Cretaceous time, followed by two events at between 32 and $3.5 \mathrm{Ma}$ and since $3.5 \mathrm{Ma}$ that increased the range elevation to the $4000 \mathrm{~m}$ observed elevation today.

\section{INTRODUCTION}

Topographic relief in active orogenic belts is a competition between erosional processes and lithospheric deformation. Recent models of orogenic evolution predict that when these two forces are in equilibrium, mountain belts will achieve a steady-state relative to topography, erosion, or mass flux (Willett and Brandon, 2002). However, many orogens contain high-elevation, lowrelief fluvial landscapes that indicate the orogen has not completely adjusted to modern erosional conditions (Epis and Chapin, 1975; Abbott et al., 1997;
Gubbels et al., 1993; Sugai and Ohmori, 1999; Clark et al., 2005) as in "type" steady-state orogens such as Taiwan. These low-relief landscapes are interpreted as paleolandscapes (or relict landscapes) that preserve information about erosional processes, erosion rate, and relief related to past tectonic and climatic conditions.

Landscape response to external forcing is largely controlled by the behavior of bedrock fluvial systems, and the topographic relief of mountain ranges, in the absence of significant glacial erosion, is set by the longitudinal profiles of rivers (Whipple et al., 1999; Densmore et al., 2005). Therefore, largescale topography of a mountain range can be altered through the adjustment of fluvial channels and neighboring hillslopes to new boundary conditions. For example, an increase in uplift rate or drop in relative base level is expected to initiate an acceleration of stream incision that will propagate upstream through the drainage network followed by changes in river channel slope, hillslope relief, and mean erosion rates (Whipple and Tucker, 1999; Crosby and Whipple, 2005, and references therein).

Before complete adjustment to new boundary conditions, remnants of relict landscape are distinguishable from equilibrated regions by a contrast in hillslope and channel gradients, dominant erosional processes, and erosion rates. Non-equilibrium landscapes in active orogens suggest that under some conditions this transient condition can persist for up to several tens of m.y. Long response times may allow relict landscapes to become decoupled from modern tectonic conditions and therefore become passive markers to vertical displacements of Earth's surface (Clark et al., 2005). This decoupling allows us to use properties of the relict landscape to characterize paleorelief.

While elevation changes in the Sierra Nevada bear directly on several lithospheric-scale geodynamic processes proposed for the western Cordillera, the elevation history of the range remains hotly debated. Several studies argue for an increase in range elevation in late Cenozoic time. Sedimentary evidence suggests that an increase of up to $2 \mathrm{~km}$ since $10 \mathrm{Ma}$ has occurred due to block faulting and westward tilting of the range (Le Conte, 1880; Huber, 1981; Unruh, 1991; Wakabayashi and Sawyer, 2001). Similarly, Stock et al. (2004, 2005) document accelerated river incision between 2.7 and 1.4 Ma in the Kings River canyon, which they relate to a tectonically driven increase in mean elevation. In contrast, apatite (U-Th)/He cooling ages were interpreted to suggest significant paleoelevation since Late Cretaceous time, lowering toward the present (House et al., 1997, 1998, 2001), and oxygen-isotope data from the western Basin and Range province suggest that the Sierra Nevada was a prominent orographic barrier since at least middle Miocene time (Poage and Chamberlain, 2002). Reconciliation of conflicting observations in the geologic, geomorphic, and thermochronometric records is needed to improve our understanding of the paleotopography, geodynamic history, and tectonic processes of the region. In the following sections, we address the current debate over the paleoelevation from a study combining geomorphologic analyses with low-temperature thermochronometry.

\section{TOPOGRAPHY OF THE SOUTHERN SIERRA NEVADA}

The northern Sierra Nevada is a uniformly west-tilted fault block, but the southern Sierra Nevada is more complex (Huber, 1981; Unruh, 1991; Wakabayashi and Sawyer, 2001). Mean and peak elevations rise continuously southward to Mount Whitney and then decrease steeply. The eastern range front follows this trend with its highest relief at Mount Whitney. The morphology of the western margin is also more complicated in the south. North of $37^{\circ} \mathrm{N}$, Cenozoic strata homoclinally lap off the 
west flank of the range. South of $37^{\circ} \mathrm{N}$, the range front is embayed by a zone of active subsidence between $37^{\circ} \mathrm{N}$ and $36^{\circ} \mathrm{N}$ and distorted by normal-fault-controlled uplifts, including the Bakersfield Arch farther south (Blackwelder, 1927; Gilbert, 1928; Saleeby and Foster, 2004) (Fig. 1). These differences suggest that the southern Sierra Nevada may have an elevation history distinct from the simple fault-block model proposed farther north.

Below the limit of Plio-Pleistocene glaciation, south of the San Joaquin River, we observe dissected low-relief upland surfaces developed on basement rocks (Fig. 1). These surfaces trace northward into a low-relief nonconformity at the base of a fluvial and volcanic Eocene to Miocene section that laps off the west flank of the northern Sierra (Fig. 1) (Huber, 1981). This observation suggests that the upland surfaces were formed by fluvial processes prior to Eocene time. The upland surfaces decrease in elevation southward from the latitude of Mount Whitney but do not dip westward, consistent with the southerly slope of this part of the range.

Some of the upland surfaces have been explained as a progression of erosional stages of the Sierra Nevada (Lawson, 1904, 1936; Matthes, 1937, 1960; Webb, 1946) or as products of unique weathering properties of granite (Wahrhaftig, 1965). These studies identified both small-scale planar features in the landscape as well as more extensive regions of low relief and related them qualitatively to the topographic evolution of the range, but the lack of dating techniques prohibited quantitative assessments of erosion rate or landscape age. We restrict our definition of "surface" to low-relief portions of the landscape that are within the fluvial network. This is a critical distinction from some earlier studies because we suggest that the relief on the upland surfaces is set by fluvial erosional processes responding to a common base level set by the major trunk streams. Because we consider upland surfaces to be remnants of a once continuous, relict fluvial landscape eroded to a common base level, we are able to correlate the erosion history of adjacent basins in order to interpret elevation changes that affected the entire range.
The relict landscape is characterized by low to moderate hillslope relief (local slopes mostly $<10^{\circ}$; local relief $<500 \mathrm{~m}$ ) and is dominated by transport-limited (alluvial) rivers (Fig. 2). Many hillslopes are mantled by deeply weathered granite with occasional outcrops of intact bedrock. Tors and short cliffs are common on hillslopes, especially at high elevation and in areas of jointed bedrock. Small basins of coarse grus produced by hillslope weathering are common along segmented reaches of streams, separated by short, narrow bedrock reaches. Isolated remnants of Miocene through Quaternary age

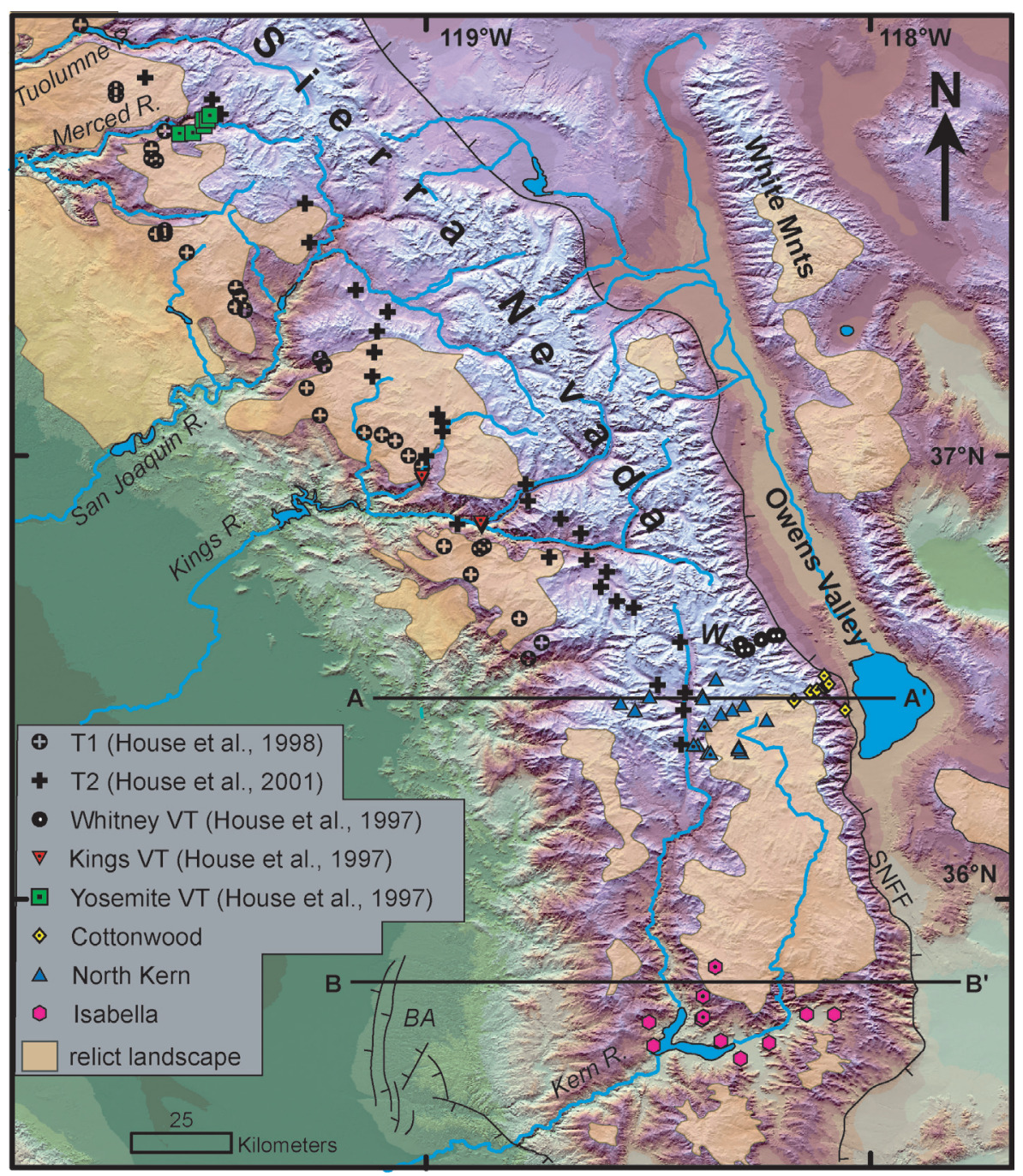

Figure 1. Shaded relief map of the southern Sierra Nevada, California. Locations of (U-Th)/He samples shown by symbols. Center dots indicate samples used for vertical transects (VT) in Fig. 4A. Horizontal profiles are shown by lines A and B (Fig. 4B). Low-relief, upland surfaces are outlined in orange. BA-Bakersfield Arch; SNFF—Sierra Nevada Frontal Fault; W-Mount Whitney.

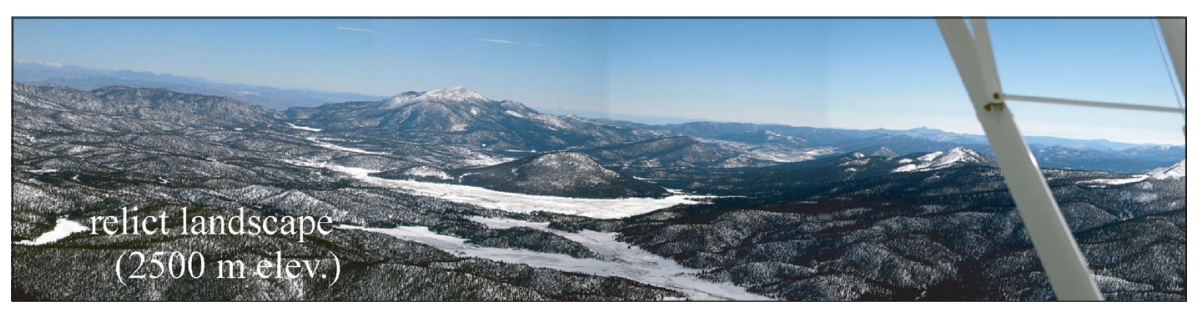

Figure 2. Example of the relict landscape of the southern Sierra Nevada. 
volcanic rocks mantle these surfaces, which otherwise lack depositional cover (Bergquist and Nitkiewicz, 1982; Smith, 1964).

\section{FLUVIAL ANALYSES}

We exploit the fact that fluvial systems erode to a common base level. Throughout Late Cretaceous to Miocene time, the paleoshoreline lay just west and south of the Sierra Nevada, suggesting that the major rivers of the range were graded to sea level (Cox, 1987; Nilsen, 1987; Bartow, 1984, 1991). We use short channel segments on the relict landscape to reconstruct paleorelief using a scaling law that relates local channel slope $(S)$ to drainage area $(A)$, where drainage area is a proxy for discharge, through the channel parameters of steepness $\left(k_{s}\right)$ and concavity $(\theta)$ (e.g., Flint, 1974):

$$
\mathrm{S}=\mathrm{k}_{\mathrm{S}} \mathrm{A}^{-\theta} \text {. }
$$

We identify channel segments on the relict landscape as the upstream portion of the channel above major knickpoints or changes in concavity (Fig. 3). In the field, this transition is associated with an increase in local hillslope gradient and a change from alluvial-dominated to bedrock-dominated processes in the channel bed downstream of the relict landscape. Channel parameters measured from stream segments on the relict landscape are used to extrapolate the original stream profile downstream to the confluence with the major trunk rivers (Schoenbohm et al., 2004, and references therein; methods described in GSA Data Repository ${ }^{1}$ ). This reconstruction provides a measure of both paleorelief on tributary basins and the total amount of river incision below the relict landscape (Fig. 3).
Many stream profiles exhibit two major knickpoints, suggesting that two phases of increased river incision rate occurred in the formation of the modern steep river canyons. Using only the channel segment on the relict landscape (i.e., upstream of the highest knickpoint), average concavity values for the Kings and Kern rivers are $\theta=0.40 \pm 0.09$ ( $1 \sigma)$ and $\theta=0.41 \pm 0.1$ with normalized steepness values of $k_{s(\text { norm })}$ $=28.5 \pm 12.8$ and $k_{s(\text { norm })}=25.1 \pm 12.3$, respectively (Tables DR4 and DR5 [see footnote 1]). Steepness values vary strongly as a function of the concavity, so we calculate the normalized steepness value for each stream determined by a linear regression to slope-area data for a fixed concavity equal to the average concavity value for tributaries in that basin (Kirby et al., 2003, and references therein; see also supplemental text and Tables DR4 and DR5 in the GSA Data Repository [see footnote 1]). Relict tributary relief for the Kings River ranges from 270 to $1340 \mathrm{~m}$, and total incision ranges from 730 to $1660 \mathrm{~m}$. Relict tributary relief on the Kern River ranges from 150 to $970 \mathrm{~m}$, and total incision ranges from 360 to $1380 \mathrm{~m}$. The total amount of incision and paleotributary relief varies primarily as a function of distance along the main trunk river with maximum values located in the center of the drainage basin (Tables DR4 and DR5 [see footnote 1]). In the following sections, we examine long-term erosion rates in order to establish a chronology of relief production.

\section{EROSION RATES}

Apatite (U-Th)/He thermochronometry constrains long-term erosion rates because helium ages record the time at which
A
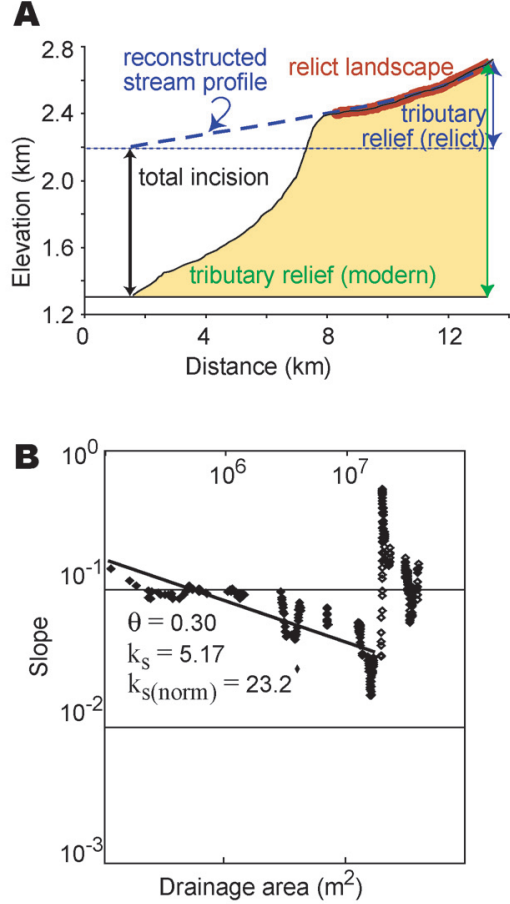
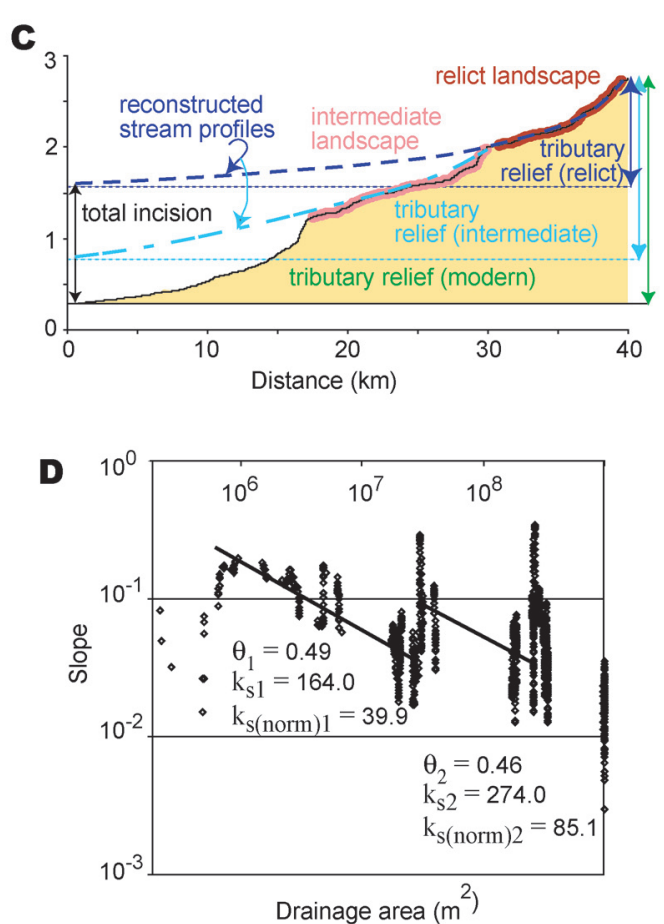

Figure 3. Examples of reconstructed tributary profiles. Solid lines in A and C are actual stream profiles; dashed lines are reconstructed profiles. The reconstructed profile is based on best-fit channel parameters (concavity $[\theta]$; steepness $\left[k_{s}\right]$ ) for a power-law relationship between drainage area and local channel slope (e.g., Flint, 1974) using channel segments on the relict landscape (red). Normalized steepness values $\left[k_{s(\mathrm{norm})}\right]$ are also given for average concavity values (Tables DR4 and DR5; Figs. DR1 and DR2 [see text footnote 1]). (A) Durrwood Creek, tributary to Kern River. Relict tributary relief is the vertical distance between the channel head and the reconstructed channel at the confluence with the main trunk stream (blue). The vertical distance between the reconstructed channel at the confluence and the modern stream elevation is an estimate of the local channel incision below the relict landscape (Tables DR4 and DR5 [see text footnote 1]). (B) Slope-area plot for local channel segments along the stream profile. Line represents best fit to the data for the channel segment on the relict landscape [red in (A)]. (C) Bear Creek-Dinky Creek-N. Fork Kings River, tributary to Kings River, shows two major knickpoints on the channel profile. Middle channel segment represents an intermediate stage of relief production (pink). (D) Slope-area plot for local channel segments along the stream profile. Line represents best fit to the data for the channel segment on the relict landscape [red in (A) and (C)] and the intermediate landscape [pink in (C)].

${ }^{1}$ GSA Data Repository Item 2005166, methods and analytical techniques and references, Tables DR1-DR5 (stream analyses, sample locations, and age data), and Figures DR1 and DR2 (location maps), is available online at www.geosociety.org/pubs/ft2005.htm or on request from Documents Secretary, GSA, P.O. Box 9140, Boulder, CO 80301-9140, USA, or editing@geosociety.org. 
a rock cools through $\sim 70{ }^{\circ} \mathrm{C}$, or $\sim 2-4$ $\mathrm{km}$ deep in the crust (Wolf et al., 1996; Farley, 2002). The slope of helium age versus elevation for samples collected along a vertical transect, such as along a ridge line or canyon wall, is a measure of erosion rate over m.y. time scales. Three new helium age transects were collected south of Mount Whitney (Fig. 1; Tables DR1 and DR2 [see footnote 1]). These transects yield erosion rates of $0.04-0.06 \mathrm{~mm} / \mathrm{yr}$ during the time interval from 73 to 47 Ma for two profiles in the Kern River (N. Kern and Isabella) and from 53 to $11 \mathrm{Ma}$ for one profile on the eastern escarpment (Cottonwood). These rates agree with those from Mount Whitney and northward (House et al., 1997, 2001) (Fig. 4A).

We use the average elevation of the relict landscape at each sampling locality as a measure of the paleoland surface and plot each transect as depth below this horizon (Fig. 4A; Table DR3 [see footnote 1]). The remarkable agreement among the profiles strongly indicates that the geothermal gradient and timing and rate of erosion are uniform across the entire study area. This observation is contrary to the expectations of Jones et al. (2004) that lateral variations in heat production are significant enough to perturb the age pattern. The helium ages suggest that $<2 \mathrm{~km}$ of erosion of the relict landscape has occurred since $80 \mathrm{Ma}$, a conclusion consistent with igneous geobarometry from the Whitney region (Ague and Brimhall, 1988). The slope of the age-depth profile indicates an average erosion rate of $0.04 \mathrm{~mm} / \mathrm{yr}$ continuing at least until $32 \mathrm{Ma}$ in the Kings River drainage and to $11 \mathrm{Ma}$ on the eastern escarpment. The two eastern profiles are located in the footwall of a normal fault and expose deeper crustal sections than the river canyon transects to the west and south, and the slow post-32 Ma erosion they imply may or may not extend to the Kings and Kern River regions. Therefore, we conservatively estimate the period of slow erosion in the major river canyons to extend to $32 \mathrm{Ma}$, the youngest helium age on the Kings River transect (Fig. 4). These slow long-term erosion rates are similar to short term rates derived from cosmogenic isotopes. Granitic surfaces in the Kings River catchment eroded at $0.012 \mathrm{~mm} / \mathrm{yr}$ over
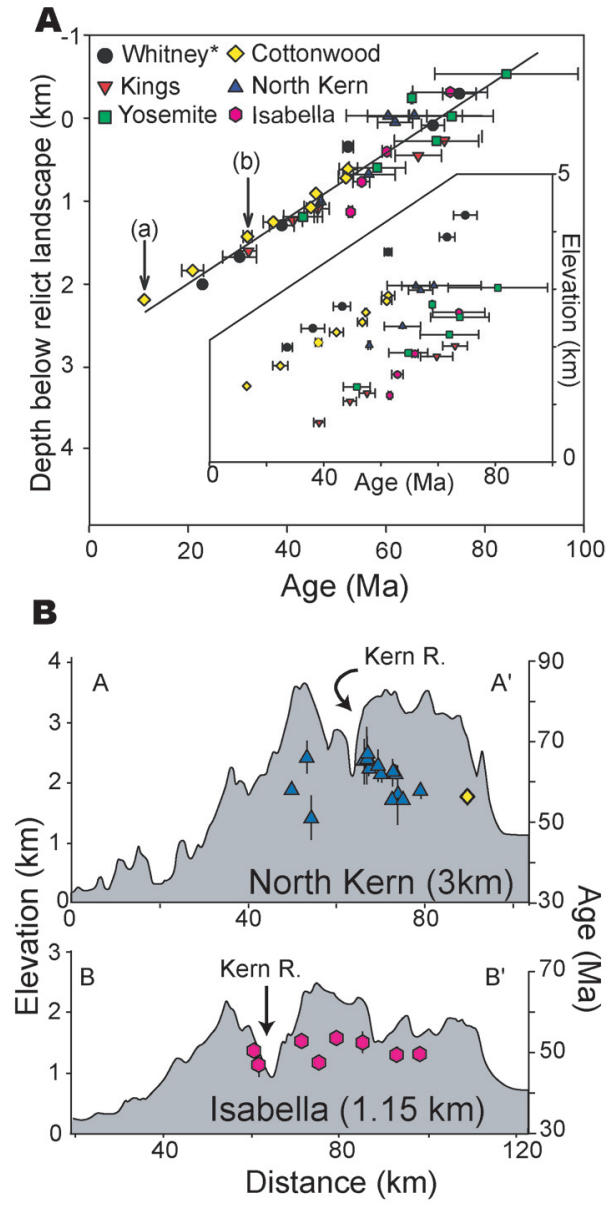

Figure 4. Apatite (U-Th)/He ages. (A) Ages versus depth below the average elevation of the relict landscape in the locality of the transect (see Tables DR1 and DR3 [see text footnote 1]). Some samples were collected from local highs that are above the average elevation of the relict landscape. Whitney, Yosemite, and Kings profiles (House et al., 1997, 2001) and Cottonwood, N. Kern and Isabella (this study). *For Mount Whitney profile, as no relict landscape is recognized in this area, the mean elevation $(4000 \mathrm{~m})$ of the area was used. Arrows (a) and (b) represent youngest helium age for the eastern and western Sierra, respectively. Inset shows age versus elevation for each transect. (B) Horizontal transects compared to topography (gray, left vertical axis). Samples were collected at a constant elevation $( \pm 100 \mathrm{~m})$ and are plotted as a function of distance along the profile versus age (right vertical axis). Profile locations are given in Figure 1.

the last 75 k.y. (Stock et al., 2004) and basin-averaged erosion rates from lowrelief upland surfaces in the northern Sierra range from 0.015 to $0.075 \mathrm{~mm} / \mathrm{yr}$ for time scales on the order of $10^{4}-10^{5} \mathrm{yr}$ (Riebe et al., 2000).
While helium ages record slow erosion rates from 80 to $32 \mathrm{Ma}$, late Pliocene-early Quaternary incision rates are much higher. Cosmogenic burial ages from cave sediments in the Kings River (Stock et al., 2004) indicate an incision rate of $0.27 \mathrm{~mm} / \mathrm{yr}$ between 2.7 and $1.4 \mathrm{Ma}$, and volcanic capped river terraces in the central Kern River suggest an average incision rate of $1.1 \mathrm{~mm}$ / yr since 3.5 Ma (Dalrymple, 1963; Ross, 1986). However, these data directly record channel lowering, whereas the helium ages record an averaged erosion rate that encompasses both channel incision as well as local hillslope erosion. The acceleration of incision since at least $3.5 \mathrm{Ma}$ in the southern Sierra can be related to the most recent propagation of an erosional signal through the fluvial network (Stock et al., 2005). This phase is likely related to the lowest elevation knickpoint on the tributary profiles (Stock et al., 2005) and to the prominent $<3.5$ Ma basalt-capped river terrace along the main Kern River (Dalrymple, 1963; Ross, 1986). Our youngest helium age on the west side of the range demands that slow erosion $(0.04 \mathrm{~mm} / \mathrm{yr})$ continued until at least 32 $\mathrm{Ma}$, so the initial onset of accelerated incision occurred sometime between 32 and $3.5 \mathrm{Ma}$.

\section{PALEORELIEF ESTIMATES}

Variations in surface topography result in perturbation of shallow isotherms (e.g., Stüwe et al., 1994). Therefore, samples collected along a horizontal profile at constant elevation may show variations in helium age that relate to paleorelief (House et al., 1998, 2001). Apatite samples collected parallel to the western front of the range at 2000 $\mathrm{m}$ yield early Cenozoic helium ages that negatively correlate with the modern relief of major river basins (House et al., 1998, 2001). House et al. (1998, 2001) found that ages vary 20-30 m.y. over a $70 \mathrm{~km}$ wavelength across the canyons and interfluves of the San Joaquin and Kings rivers area. Assuming steady erosion of $0.05 \mathrm{~mm} / \mathrm{yr}$, these authors found the age variation to be consistent with 1-2 km of paleorelief (House et al., 2001). Ages from samples collected interior to the range and north of the San Joaquin-Kings area do not vary with topography, which is consistent 
with negligible paleorelief $(<1 \mathrm{~km})$ in the upstream portions of the San Joaquin and Kings Rivers and north of the San Joaquin River.

We collected two new horizontal transects from the Kern River area (Fig. 1). The northern profile at $3000 \mathrm{~m}$ elevation (North Kern) yields ages in the range of 55-65 Ma with older ages near the Kern River. There is a systematic westward increase in age on the east side the river (Fig. 5A), but apatite quality and yield precluded the dense sampling necessary to evaluate the age variation west of the river. These age variations could be consistent with either west tilting or paleorelief on the Kern River drainage basin. Following the model of House et al. (2001), the North Kern age variation of $\sim 10$ m.y. may indicate $\sim 1 \mathrm{~km}$ of paleorelief across this basin from ca. 80 to $43 \mathrm{Ma}$. The southern transect (Isabella) shows no age variation across the range (Fig. 5B). This lack of eastwest age variation and the southerly slope of this portion of the range suggest that the southern Sierra Nevada is tilted south and not west.

Samples collected in the glaciated portion of the range (Whitney and North Kern samples at $>36.4^{\circ} \mathrm{N}$ latitude) are not systematically younger than depth-equivalent samples in unglaciated areas. The sensitivity of our measurement and scatter of data between adjacent samples (conservatively, $10 \%$ ) equates to variability of $<8$ m.y. (Fig. 4A). At an erosion rate of $0.04 \mathrm{~mm} / \mathrm{yr}$, an age variation of $<8 \mathrm{~m}$.y. suggests that no more than $\sim 300 \mathrm{~m}$ of glacial erosion has occurred.

Estimates of paleorelief from the helium data are consistent with the reconstructed tributary relief on the relict landscape (Fig. 3), suggesting that the relict landscape is similar to the Late Cretaceous landscape. Using average channel parameters for tributaries on the relict landscape, we reconstruct the paleoelevation profile for the main Kern and Kings Rivers. The height of these reconstructed channels, plus a typical 100 $\mathrm{m}$ hillslope relief at the channel head, provides an estimate of the paleocrest elevation of the southern Sierra Nevada. Using Equation (1), we calculate the channel profile by assuming sea-level elevation at the modern bedrock-alluvial transition at the western edge of the range, which would have been near or at the Cretaceous shoreline (Cox, 1987; Nilsen, 1987; Bartow, 1984, 1991) and by assuming no changes in drainage-basin areal geometry. Our calculations yield $1390 \pm 680$ $\mathrm{m}$ and $1500 \pm 630 \mathrm{~m}$ elevation for the paleo-headwaters of the Kern and Kings Rivers, respectively (Fig. 5). The Kern and Kings rivers are oriented $\sim 90^{\circ}$ to each other and share a drainage divide. Therefore, we expect the headwaters of each of these rivers to lie at approximately the same elevation. The close agreement between our two profiles provides an internal consistency check on our reconstructions.

\section{DISCUSSION}

By comparison with modern ranges like the Andes, House et al. (2001) scaled the 1-2 km of paleorelief implied by thermochronometry to a range crest elevation of 3-4 km. We estimate the paleoelevation of the range using a different approach: using the helium data to suggest that the relict landscape is representative of the Sierran landscape in Late Cretaceous time, and reconstructing the fluvial relief of the Kings and Kern rivers based on the properties of the relict landscape (Fig. 5). Because the Late Cretaceous shoreline is shown in the subsurface west of the current eastern edge of the San Joaquin Valley (Bartow, 1991), the Kings River would have graded to sea level and the paleofluvial relief of the main river can be used to estimate $\sim 1500 \mathrm{~m}( \pm 650 \mathrm{~m})$ crestal elevation of the range in Late Cretaceous time, or $\sim 2500 \mathrm{~m}$ less than today.

Two prominent knickpoints on many stream profiles and an extensive bedrock terrace level developed along the main Kern River suggest that the increase in late Cenozoic elevation was associated with at least two phases of rapid river incision (Fig. 3C). The most recent pulse began $\leq 3.5 \mathrm{Ma}$ in the Kern River (Dalrymple, 1963; Ross, 1986) and between 2.7 and 1.4 Ma in the central Kings River (Stock et al., 2004), both of which account for $\sim 350-400 \mathrm{~m}$ of most recent incision in the central portions of these basins. At present, we lack data that allow us to determine when accelerated incision first began within the interval of $32-3.5 \mathrm{Ma}$. Application of the ${ }^{4} \mathrm{He} /{ }^{3} \mathrm{He}$ thermochronology method, which is sensitive to even lower temperatures $\left(40^{\circ} \mathrm{C}\right.$ ), is one promising alternative (Shuster and Farley, 2004).

The youngest phase of accelerated erosion $(\leq 3.5 \mathrm{Ma})$ is consistent with both Pliocene climate change (Small and Anderson, 1995; Zhang et al., 2001) and removal of a dense, eclogitic root from beneath the range (Jones et al., 1994; Ducea and Saleeby, 1996; Farmer et al., 2002; Saleeby and Foster, 2004; Jones et al., 2004; Zandt et al., 2004; Boyd et al., 2004). The timing of the earlier pulse is needed to assess its

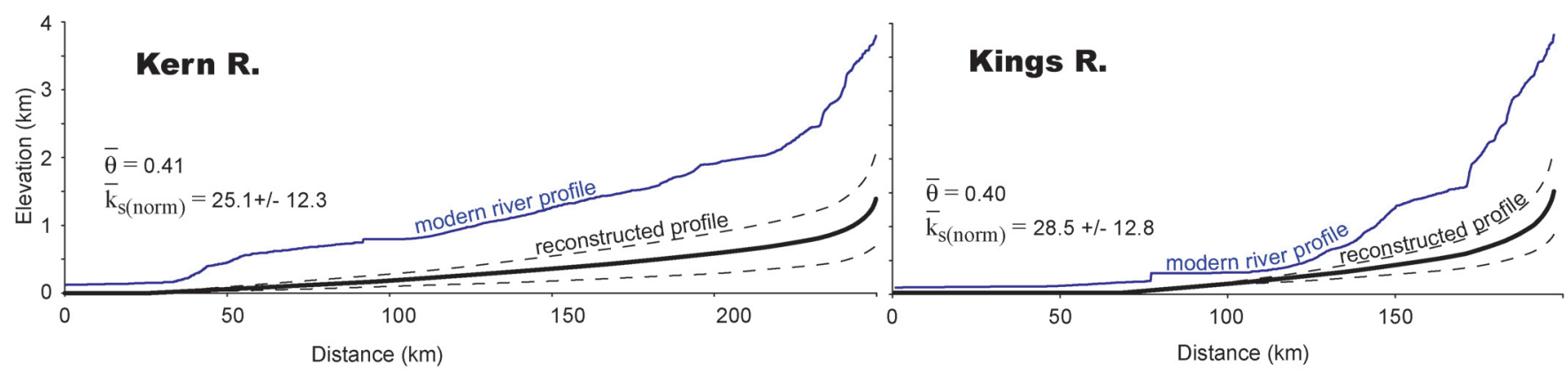

Figure 5. Modern (blue) and reconstructed (black) river profiles for trunk streams. Reconstructed profile is calculated from average concavity $(\theta)$ and average normalized steepness $\left[k_{s(n o r m)}\right]$ values determined from channel segments on the relict landscape (Tables DR4 and DR5; Figures DR1 and DR2 [see text footnote 1]). Dashed lines show $\pm 1 \sigma$ of normalized steepness values. 
possible relation to any one of several different proposed tectonic and geodynamic phenomena, such as (1) an early stage of lithospheric foundering and replacement by buoyant asthenosphere (Ducea and Saleeby, 1996); (2) passage of the slab-window (Atwater and Stock, 1998); (3) early faulting related to the opening of Owens Valley (Maheo et al., 2004); or (4) upwelling of asthenospheric mantle observed in the adjacent region beneath the Owens Valley and the eastern Mojave Desert (DePaolo and Daly, 2000). Estimates of paleoelevation of the range crest are not consistent with a decrease in elevation during Cenozoic time caused by evacuation of silicic crust eastward to the extending Basin and Range province (Wernicke et al., 1996). Moderate elevations ( $1500 \mathrm{~m}$ ) could explain the midMiocene orographic barrier (Poage and Chamberlain, 2002), but do not support a model of decreasing elevation in late Cenozoic time.

\section{CONCLUSION}

The non-equilibrium condition of the Sierra Nevada allows us to quantitatively construct the topographic evolution of the Sierra Nevada using modern topography, field observations, thermochronometry, and cosmogenically derived erosion rates. Helium ages suggest that a constant erosion rate of $0.04 \mathrm{~mm} / \mathrm{yr}$ prevailed from ca. 80 to ca. $32 \mathrm{Ma}$, and variations in helium ages across major drainage basins suggest that $1-2 \mathrm{~km}$ of maximum relief existed during this time period (House et al. 2001; this study). We posit that this landscape is represented by low-relief, upland surfaces preserved throughout the southern range. This $1-2 \mathrm{~km}$ of relief probably represents the fluvial relief on major tributaries of the ancestral Kings and San Joaquin Rivers. Longitudinal river profiles and channel slope-drainage area relationships suggest that two episodes of accelerated river incision followed this initial period of slower erosion. Reconstruction of channel profiles that originate on the relict landscape suggests that $150-1660$ m of relief existed in tributary basins. In particular, reconstructed relief on the largest tributary basins where thermochronometric data were collected is between 1000 and $1300 \mathrm{~m}$, which is in excellent agreement with the $1-2 \mathrm{~km}$ of paleorelief inferred from the helium data from the same localities. Using channel parameters measured from stream segments on the relict landscape, we can reconstruct the total paleorelief on the Kings and Kern Rivers and suggest that a modest range elevation of $1500 \mathrm{~m}$ existed between Late Cretaceous and Miocene time. Based on published data, 350-400 m of our calculated 1380-1660 m maximum incision in the central Kings and Kern Rivers occurred in the past 3.5 m.y. Rapid incision beginning between ca. 32 and 3.5 Ma may relate to either protracted surface uplift associated with Basin and Range faulting or density changes in the lithosphere, such as by convective removal of a lithospheric root, by upwelling asthenosphere, or by passage of a slab window.

\section{ACKNOWLEDGMENTS}

This work was supported by National Science Foundation grants EAR-0230383 (Saleeby and Farley), EAR-0105981 (Farley), and EAR-0087347 (Saleeby); the Texaco Prize Postdoctoral Fellowship (Clark); and the Caltech Tectonics Observatory. We thank L. Hedges and C. Paine for analytical assistance, and T. Gannon (Clear Creek Systems, Inc., Bakersfield, California) for flight time and field assistance. Reviews provided by M. Brandon, S. Brocklehurst, D. Malmon, M. Oskin, and G. Stock greatly improved this manuscript.

\section{REFERENCES CITED}

Abbott, L.D., Silver, E.A., Anderson, R.S., Smith, R., Ingle, J.C., Kling, S.A., Haig, D., Small, E., Galewsky, J., and Sliter W., 1997, Measurement of tectonic surface uplift rate in a young collisional mountain belt: Nature, v. 385, p. 501507, doi: 10.1038/385501a0.

Ague, J.J., and Brimhall, G.H., 1988, Magmatic arc asymmetry and distribution of anomalous plutonic belts in the batholiths of California: Effects of assimilation, crustal thickness, and depth of crystallization: Geological Society of America Bulletin, v. 100, p. 912-927, doi: 10.1130/00167606(1988)100<0912:MAAADO>2.3.CO;2

Atwater, T., and Stock, J., 1998, Pacific-North American plate tectonics of the Neogene southwestern United States: An update: International Geology Review, v. 40, p. 375-402.

Bartow, J.A., 1984, Geologic map and cross-sections of the southeastern margin of the San Joaquin Valley, California: U.S. Geological Survey Miscellaneous Investigations Series Map 1-1496, scale 1:125,000.

Bartow, J.A., 1991, The Cenozoic evolution of the San Joaquin Valley, California: U.S. Geological Survey Professional Paper 1501, 40 p.

Bergquist, J.R., and Nitkiewicz, A.M., 1982, Geologic map of the Domeland Wilderness and contiguous roadless areas, Kern and Tulare counties, California: U.S. Geological Survey Miscellaneous Field Studies Map MF-1395-A, scale 1:48,000

Blackwelder, E., 1927, Scarp at the mouth of the Kern River Canyon: Geological Society of America Bulletin, v. 28, p. 207.

Boyd, O.S., Jones, C.H., and Sheehan, A.F., 2004,

Foundering lithosphere imaged beneath the southern Sierra Nevada, California, USA: Science, v. 305, p. 660-662, doi: 10.1126/science.1099181.

Clark, M.K., Royden, L.H., Whipple, K.X., Burchfiel, B.C. Zhang, X., and Tang, W., 2005, Deformation of a regional low-relief landscape (erosion surface) in eastern Tibet: Journal of Geophysical Research, Earth Surface (in press).
Cox, B.F., 1987, Stratigraphy, depositional environments, and paleotectonics of the Paleocene and Eocene Golar Formation, El Paso Mountains, California—geologic summary and roadlog, in Cox, B.F., ed., Basin analysis and paleontology of the Paleocene and Eocene Golar Formation, El Paso Mountains, California: Pacific Section, Society of Economic Paleontologists and Mineralogists (SEPM), Guidebook 57, p. 1-29.

Crosby, B.T., and Whipple, K.X., 2005, Knickpoint initiation and distribution within fluvial networks: 236 waterfalls in the Waipaoa River: North Island, New Zealand: Geomorphology (in press).

Dalrymple, G.B., 1963, Potassium-argon dates of some Cenozoic volcanic rocks of the Sierra Nevada, California: Geological Society of America Bulletin, v. 74, p. 379-390.

Densmore, A., Dawers, N.H., Gupta, S., and Guidon, R., 2005, What sets topographic relief in extensional footwalls? Geology, v. 33, p. 453-456, doi: 10.1130/G21440.1.

DePaolo, D.J., and Daly, E.E., 2000, Nd isotopes in basalts of the southwest Basin and Range Province and lithospheric thinning during continental extension: Chemical Geology, v. 169, p. 157-185, doi: 10.1016/S0009-2541(00)00261-8

Ducea, M.N., and Saleeby, J.B., 1996, Buoyancy sources for a large unrooted mountain range, the Sierra Nevada, California: Evidence from xenolith thermobarometry: Journal of Geophysical Research, v. 101, p. 8229-8241, doi: 10.1029/95JB03452.

Epis, R.C., and Chapin, C.E., 1975, Geomorphic and Tectonic implications of the post-Laramide, late Eocene erosion surface in the southern Rocky Mountains: Geological Society of America Memoir 144, p. 45-74.

Farley, K.A., 2002, (U-Th)/He dating: Techniques, calibrations, and applications, in Noble gases in geochemistry and cosmochemistry: Reviews in Mineralogy and Geochemistry v. 47 , p. $819-844$.

Farmer, G.L., Glazner, A.F., and Manley, C.R., 2002, Did lithospheric delamination trigger late Cenozoic potassic volcanism is the southern Sierra Nevada, California?: Geological Society of America Bulletin, v. 114, no. 6, p. 754-768, doi: 10.1130/0016-7606(2002)114<0754: DLDTLC>2.0.CO;2.

Flint, J.J., 1974, Stream gradient as a function of order, magnitude and discharge: Water Resources Research, v. 10 p. 969-973.

Gilbert, G.K., 1928, Studies of Basin and Range structure: U.S. Geological Survey Professional Paper 153, 92 p.

Gubbels, T.L., Isacks, B.L., and Farrar, E., 1993, Highlevel surfaces, plateau uplift, and foreland development: Bolivian Central Andes, Geology, v. 21, p. 695-698, doi: 10.1130/0091-7613(1993)021<0695:HLSPUA>2.3.CO;2.

House, M.A., Wernicke, B.P., Farley, K.A., and Dumitru, T.A., 1997, Cenozoic thermal evolution of the central Sierra Nevada, California, from (U-Th)/He thermochronometry: Earth and Planetary Science Letters, v. 151, p. 167-179, doi: 10.1016/S0012-821X(97)81846-8.

House, M.A., Wernicke, B.P., and Farley, K.A., 1998, Dating topography of the Sierra Nevada, California, using apatite (U-Th)/He ages: Nature, v. 396, p. 66-69, doi: $10.1038 / 23926$.

House, M.A., Wernicke, B.P., and Farley, K.A., 2001, Paleogeomorphology of the Sierra Nevada, California, from (UTh)/He ages in apatite: American Journal of Science, v. 301 p. 77-102.

Huber, N.K., 1981, Amount and timing of Late Cenozoic uplift and tilt of the central Sierra Nevada, CaliforniaEvidence from the Upper San Joaquin River Basin: U.S. Geological Survey Professional Paper 1197, p. 1-28.

Jones, C.H., Kanimori, H., and Roecker, S.W., 1994, Missing roots and mantle "drips": Regional $P_{n}$ and teleseismic arrival times in the southern Sierra Nevada and vicinity, California: Journal of Geophysical Research, v. 99, p. 4567-4601, doi: 10.1029/93JB01232.

Jones, C.H., Farmer, G.L., and Unruh, J., 2004, Tectonics of Pliocene removal of lithosphere of the Sierra Nevada, California: Geological Society of America Bulletin, v. 116, p. 1408-1422, doi: 10.1130/B25397.1.

Kirby, E., Whipple, K.X., Tang, W., and Chen, Z., 2003, Distribution of active rock uplift along the eastern margin of the Tibetan Plateau; inferences from bedrock channel longitudinal profiles: Journal of Geophysical Research, v. 108, doi: 10.1029/2001JB0000861. 
Lawson, A.C., 1904, The geomorphogeny of the upper Kern Basin: University of California Publications in Geological Sciences, Bulletin 3, p. 291-376.

Lawson, A.C., 1936, The Sierra Nevada in the light of isostasy: Geological Society of America Bulletin, v. 47 , p. $1691-1712$.

Le Conte, J., 1880, Old river beds of California: American Journal of Science, v. 19, p. 176-190.

Maheo, G., Farley, K.A., and Clark, M.K., 2004, Cooling and exhumation of the Sierra Nevada batholith in the Moun Whitney area (California) based on ( $\mathrm{U}-\mathrm{Th}) / \mathrm{He}$ thermochronometry: Eos (Transactions, American Geophysical Union), v. 85, Fall Meeting Supplement, Abstract T41D-1252.

Matthes, F.E., 1937, The geologic history of Mount Whitney: Sierra Club Bulletin, v. 22, p. 1-18.

Matthes, F.E., 1960, Reconnaissance of the geomorphology and glacial geology of the San Joaquin Basin, Sierra Nevada, California: U.S. Geological Survey Professional Paper 329, $62 \mathrm{p}$.

Nilsen, T.H., 1987, Stratigraphy and sedimentology of the Eocene Tejon Formation, western Tehachapi and San Emigdio Mountains, California: U.S. Geological Survey Professional Paper 1268, $110 \mathrm{p}$.

Poage, M.A., and Chamberlain, C.P., 2002, Stable isotopic evidence for a Pre-Middle Miocene rain shadow in the western Basin and Range: Implications for the paleotopography of the Sierra Nevada: Tectonics, v. 21, no. 4, 1034, doi: 10.1029/2001TC001303.

Riebe, C.S., Kirchner, J.W., Granger, D.E., and Finkel, R.C., 2000, Erosional equilibrium and disequilibrium in the Sierra Nevada, inferred from cosmogenic ${ }^{26} \mathrm{Al}$ and ${ }^{10} \mathrm{Be}$ in alluvial sediment: Geology, v. 28, p. 803-806, doi: 10.1130/0091 7613(2000)028<0803:EEADIT > 2.3.CO;2

Ross, D.C., 1986, Basement-rock correlations across the White Wolf-Breckenridge-Southern Kern Canyon Fault Zone, southern Sierra Nevada, California: U.S. Geological Survey Bulletin 1651, 25 p.

Saleeby, J., and Foster, Z., 2004, Topographic response to mantle lithosphere removal in the southern Sierra Nevada region, California: Geology, v. 32, p. 245-248, doi: 10.1130/G19958.1
Schoenbohm, L.M., Whipple, K.X., Burchfiel, B.C., and Chen, L., 2004, Geomorphic constraints on surface uplift, exhumation, and plateau growth in the Red River region, Yunnan Province, China: Geological Society of America Bulletin, v. 116, p. 895-909, doi: 10.1130/B25364.1.

Shuster, D.L., and Farley, K.A., 2004, ${ }^{4} \mathrm{He} /{ }^{3} \mathrm{He}$ thermochronometry: Earth and Planetary Science Letters, v. 217 p. 1-17, doi: 10.1016/S0012-821X(03)00595-8.

Small, E.E., and Anderson, R.S., 1995, Geomorphically driven Late Cenozoic uplift in the Sierra Nevada, California: Science, v. 270, p. 277-280.

Smith, A.R., 1964, Geologic map of California, Bakersfield sheet: California Division of Mines and Geology, scale $1: 250,000$.

Stock, G.M., Anderson, R.S., and Finkel, R.C., 2004, Pace of landscape evolution in the Sierra Nevada, California, revealed by cosmogenic dating of cave sediments: Geology, v. 32, p. 193-196, doi: 10.1130/G20197.1.

Stock, G.M., Anderson, R.S., and Finkel, R.C., 2005, Rates of erosion and topographic evolution of the Sierra Nevada, California, inferred from cosmogenic ${ }^{26} \mathrm{Al}$ and ${ }^{10} \mathrm{Be}$ concentrations: Earth Surface Processes and Landforms (in press).

Stüwe, L., White, R., and Brown, X., 1994, The influence of eroding topography on steady-state isotherms; Application to fission-track analysis: Earth and Planetary Science Letters, v. 124, p. 63-74, doi: 10.1016/0012-821X(94)00068-9.

Sugai, T., and Ohmori, H., 1999, A model of relief forming by tectonic uplift and valley incision in orogenesis:

Basin Research, v. 11, p. 43-57, doi: 10.1046/j.13652117.1999.00084.x

Unruh, J.R., 1991, The uplift of the Sierra Nevada and implications for late Cenozoic epeirogeny in the western Cordillera: Geological Society of America Bulletin, v. 103, p. 1395-1404, doi: 10.1130/0016-7606(1991)103<1395 TUOTSN $>2.3 . \mathrm{CO} ; 2$.

Wahrhaftig, C., 1965, Stepped topography of the southern Sierra Nevada, California: Geological Society of America Bulletin, v. 76, p. 1165-1190.

Wakabayashi, J., and Sawyer, T.L., 2001, Stream incision tectonics, uplift and evolution of topography of the Sierra
Nevada, California: Journal of Geology, v. 109, p. 539-562, doi: $10.1086 / 321962$.

Webb, R.W., 1946, The geomorphology of the Middle Kern River Basin, southern Sierra Nevada, California: Geological Society of America Bulletin, v. 57, p. 355-382.

Wernicke, B., Clayton, R., Ducea, M., Jones, C.H., Park, S., Ruppert, S, Saleeby J, Kent Snow, J., Squires, L., Fliedner, M., Jiracek, G., Keller, R., Klemperer, S., Luetgert, J., Malin, P., Miller, K., Mooney, W., Oliver, H., and Phinney, R., 1996 Origin of high mountains in the continents: The southern Sierra Nevada: Science, v. 271 , p. 190-193.

Whipple, K.X., and Tucker, G.E., 1999, Dynamics of the stream-power river incision model: Implications for the height limits of mountain ranges, landscape response time scales and research needs: Journal of Geophysical Research, v. 104, p. 17,661-17,674, doi: 10.1029/1999JB900120. Whipple, K.X., Kirby, E., and Brocklehurst, S.H., 1999, Geomorphic limits to climate-induced increases in topographic relief: Nature, v. 401, p. 39-42, doi: 10.1038/43375.

Willett, S.D., and Brandon, M.T., 2002, On steady states in mountain belts: Geology, v. 30, p. 175-178, doi: 10.1130/0091-7613(2002)030<0175:OSSIMB >2 .0.CO;2.

Wolf, R.A., Farley, K.A., and Silver, L.T., 1996, Helium diffusion and low temperature thermochronometry of apatite: Geochimica et Cosmochimica Acta, v. 60, p. 4231-4240.

Zandt, G., Gilbert, H., Owens, T., Ducea, M., Saleeby, J., and Jones, C.H., 2004, Active foundering of a continental arc root beneath the southern Sierra Nevada in California: Nature, v. 431, p. 41-46, doi: 10.1038/nature02847.

Zhang, P., Molnar, P., and Downs, W. R., 2001, Increased sedimentation rates and grain sizes 2-4 Myr ago due to the influence of climate change on erosion rates: Nature, v. 410 p. 891-897.

Manuscript received 15 March 2005;

accepted 4 July 2005.

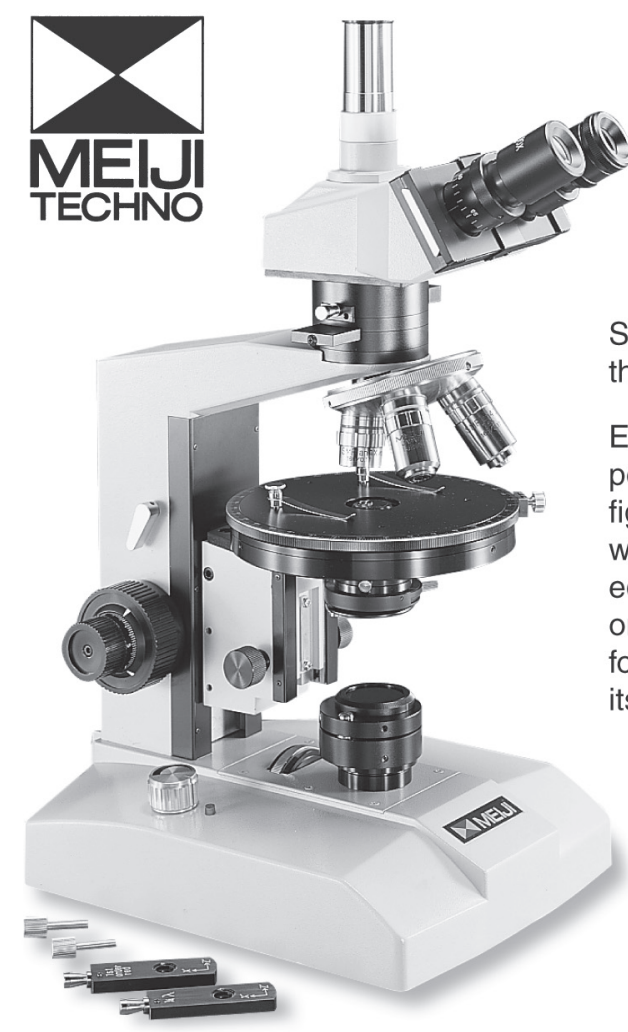

\section{Roak Solid. The Meiji ML Series of Polarizing Microscopes}

Solid as a rock and crystal clear is what you will find when you look into these Polarizing Microscopes.

Each ML 9000 Series Microscope is equipped with swing-in, swing-out polarizer, analyzer and Bertrand lens for extra-bright, extra large interface figures. Every package includes DIN standard compensators (Mica 1/4 wave plate and first order red plate), strain free optics and a $360^{\circ}$ graduated rotatable stage. You have a choice of 3 bodies - monocular, binocular or trinocular and a full range of accessories to create the ideal instrument for your specific needs and Meiji stands behind every instrument with its "Limited Lifetime Warranty."

For more information on these economically priced Microscopes, please call, FAX, write us or log on to our website today.

\section{MEIJI TECHNO AMERICA}

2186 Bering Drive, San Jose, CA 95131,

Tel: 408.428.9654, FAX: 408.428.0472

Toll Free Telephone: 800.832 .0060 or visit our website at www.meijitechno.com 